\title{
Gas Seeps at the Edge of the Gas Hydrate Stability Zone on Brazil's Continental Margin
}

\author{
Marcelo Ketzer ${ }^{1, *(\mathbb{D}}$, Daniel Praeg ${ }^{2,3,4}{ }^{6}$, Maria A.G. Pivel ${ }^{5}{ }^{(}$, Adolpho H. Augustin ${ }^{2}$, \\ Luiz F. Rodrigues ${ }^{2}$, Adriano R. Viana ${ }^{6}$ and José A. Cupertino ${ }^{2}$ \\ 1 Department of Biology and Environmental Science, Linnaeus University, 391-82 Kalmar, Sweden \\ 2 Institute of Petroleum and Natural Resources, PUCRS-Pontifícia Universidade Católica do Rio Grande do Sul, \\ Porto Alegre 90619-900, Brazil; daniel.praeg@pucrs.br (D.P.); adolpho.augustin@pucrs.br (A.H.A.); \\ frederico.rodrigues@pucrs.br (L.F.R.); jose.cupertino@pucrs.br (J.A.C.) \\ 3 LAGEMAR, Department of Geology, Universidade Federal Fluminense (UFF), Niteroi 24210-346, Brazil \\ 4 Géoazur, UMR7329 CNRS, rue Albert Einstein 250, 06560 Valbonne, France \\ 5 Centro de Estudos de Geologia Costeira e Oceânica, Instituto de Geociências, Universidade Federal do Rio \\ Grande do Sul, Porto Alegre 91501-970, Brazil; maria.pivel@ufrgs.br \\ 6 PETROBRAS_E\&P Exploration, Rio de Janeiro 20031-170, Brazil; aviana@petrobras.com.br \\ * Correspondence: marcelo.ketzer@lnu.se
}

Received: 6 March 2019; Accepted: 8 April 2019; Published: 28 April 2019

check for updates Abstract: Gas hydrate provinces occur in two sedimentary basins along Brazil's continental margin:
(1) The Rio Grande Cone in the southeast, and (2) the Amazon deep-sea fan in the equatorial
region. The occurrence of gas hydrates in these depocenters was first detected geophysically and has
recently been proven by seafloor sampling of gas vents, detected as water column acoustic anomalies
rising from seafloor depressions (pockmarks) and/or mounds, many associated with seafloor faults
formed by the gravitational collapse of both depocenters. The gas vents include typical features
of cold seep systems, including shallow sulphate reduction depths (<4 m), authigenic carbonate
pavements, and chemosynthetic ecosystems. In both areas, gas sampled in hydrate and in sediments
is dominantly formed by biogenic methane. Calculation of the methane hydrate stability zone for
water temperatures in the two areas shows that gas vents occur along its feather edge (water depths
between 510 and 760 m in the Rio Grande Cone and between 500 and 670 m in the Amazon deep-sea
fan), but also in deeper waters within the stability zone. Gas venting along the feather edge of the
stability zone could reflect gas hydrate dissociation and release to the oceans, as inferred on other
continental margins, or upward fluid flow through the stability zone facilitated by tectonic structures
recording the gravitational collapse of both depocenters. The potential quantity of venting gas on
the Brazilian margin under different scenarios of natural or anthropogenic change requires further
investigation. The studied areas provide natural laboratories where these critical processes can be
analyzed and quantified. Keywords: gas hydrates; gas seeps; ocean acidification

\section{Introduction}

Contemporary climate change is significantly impacting the marine environment. Among the most drastic impacts are declining oxygen levels [1], acidification [2], and loss of biodiversity [3]. Current estimates suggest that the ocean surface and intermediate waters $(<700 \mathrm{~m})$ could be $1-4{ }^{\circ} \mathrm{C}$ warmer at the end of this century [4]. Such an increase in temperature would promote the destabilization of gas hydrate on continental margins worldwide, even if warming is accompanied by pressure increase owing to sea-level rise [5]. Gas hydrate is still being discovered beneath the ocean margins and contain 
a large reservoir of organic carbon (mainly methane) on the Earth's surface $\left(0.5-12.7 \times 10^{21} \mathrm{~g}[6,7]\right)$, and the release of even a fraction of it to the oceans and atmosphere could potentially lead to a positive feedback in greenhouse gas emissions [8,9]. Estimates of the amount of carbon that could be released from sediments to oceans and seas owing to hydrate dissociation are poorly constrained, in part as we do not fully understand the mechanisms by which gas may move through the gas hydrate stability zone (GHSZ) and/or escape from its 'feather edge' on the upper continental slope. The feather edge of the GHSZ (i.e., the region on the upper continental slopes where it thins to vanishing at the seafloor [10]) contains about 3.5\% of the global hydrate inventory and is particularly susceptible to hydrate dissociation in response to ocean warming or sea level change $[10,11]$. Global models of the gas hydrate system response to scenarios of climate-driven change indicate that methane release to the seafloor from hydrate dissociation is greatest along the feather edge and could exceed methane fluxes from other sources by the year 2100 (i.e., $>30-50 \mathrm{Tg} \cdot \mathrm{CH}_{4} \cdot \mathrm{year}^{-1}$ [5]). Other simulations indicate that gas hydrate is sensitive to rapid temperature increases [5,12-15], and a $5^{\circ} \mathrm{C}$ increase in bottom water temperatures along continental slopes could add ca. $2000 \mathrm{Gt} \cdot \mathrm{CH}_{4}$ to sediments worldwide [16], part of which may flow toward the seafloor. It is possible that the dissociation of hydrate will also be linked to the additional release of methane by opening pathways to free gas ascending from underneath the hydrate stability zone [17].

Not all methane released by hydrate dissociation will reach the seafloor and atmosphere because it will be consumed by anaerobic oxidation via sulphate reduction in sediments [18,19], and dissolution and aerobic oxidation in the water column [20-22]. The oxidation of large quantities of methane in the water column, however, may contribute to a decrease in the ocean's pH [23,24]. In addition to its possible contribution to greenhouse gas emissions and ocean acidification, massive destabilization of gas hydrate may be associated to the triggering of submarine landslides and related tsunamis [25].

Dissociation of marine gas hydrate at the feather edge of the gas hydrate stability zone has been reported in several locations around the world [26-28]. This phenomenon received particular interest at high latitude regions owing to the high amplitude of warming in polar oceans [29-31]. The aim of the present article is to review evidence of venting from two gas hydrate provinces along Brazil's continental margin: (1) The Rio Grande Cone and (2) the upper Amazon deep-sea fan. The latter is, to our knowledge, the only case in the world where gas venting near the feather edge of the GHSZ was reported in equatorial regions. We review recent discoveries within these provinces and compare them to the calculated feather edge of the GHSZ. The results provide insights into the role of climate-driven changes in ocean conditions versus processes controlling fluid flow within continental margins, and suggest further investigations on the Brazilian margin in relation to the global carbon cycle and ongoing climate change.

\section{Gas Hydrate and Gas Venting Structures on Brazil's Continental Margin}

The presence of gas hydrate on Brazil's continental margin was first reported in the 1980s from bottom simulating reflectors (BSRs) observed in two deep-water depocenters: (1) The Rio Grande cone in the Pelotas Basin, western South Atlantic margin [32-34], and (2) the Amazon deep-sea fan in the Foz do Amazonas Basin, Equatorial Atlantic margin [35-37] (Figure 1). Other less well defined BSRs in Brazil were observed in the Campos and Santos basins [33,38]. The Rio Grande Cone forms a protuberance in the continental slope and contains a deposit of up to $12 \mathrm{~km}$ of sediments (Barremian to recent) in an area of approximately $250,000 \mathrm{~km}^{2}$. Sediments were sourced from the Rio de la Plata river [39] and/or from large contourite systems occurring to the south [40] and to the north [41]. The Amazon deep-sea fan also forms a protuberance in the continental slope and contains of a deposit of up to $10 \mathrm{~km}$ of sediments (Late Miocene to recent) sourced mainly from the Amazon River [42], and distributed in an area of $330,000 \mathrm{~km}^{2}$ [43].

Sediment loading in the Rio Grande Cone and in the Amazon deep-sea fan resulted in large-scale gravitational collapse, expressed as paired belts of extensional and compressional structures rooted on deep detachment surfaces. In contrast to the mainly stratified internal character of the Rio Grande cone, the Amazon fan is characterized by giant mass transport deposits recording sediment failure 
from the upper slope $[35,44]$. High rates of sedimentation (including organic matter), particularly in the upper Amazon fan, contribute to low geothermal gradients $\left(15-19^{\circ} \mathrm{C} / \mathrm{km}\right.$, based on BSR depth and bottom-hole temperatures; [37]), which, together with low bottom water temperatures, result in a potential thick gas hydrate stability zone. The quantity of methane trapped in gas hydrate in the two areas has been estimated to be 22 trillion $\mathrm{m}^{3}$ (ca. $780 \mathrm{tcf}$ ) and 12 trillion $\mathrm{m}^{3}$ (ca. $430 \mathrm{tcf}$ ), respectively [45].

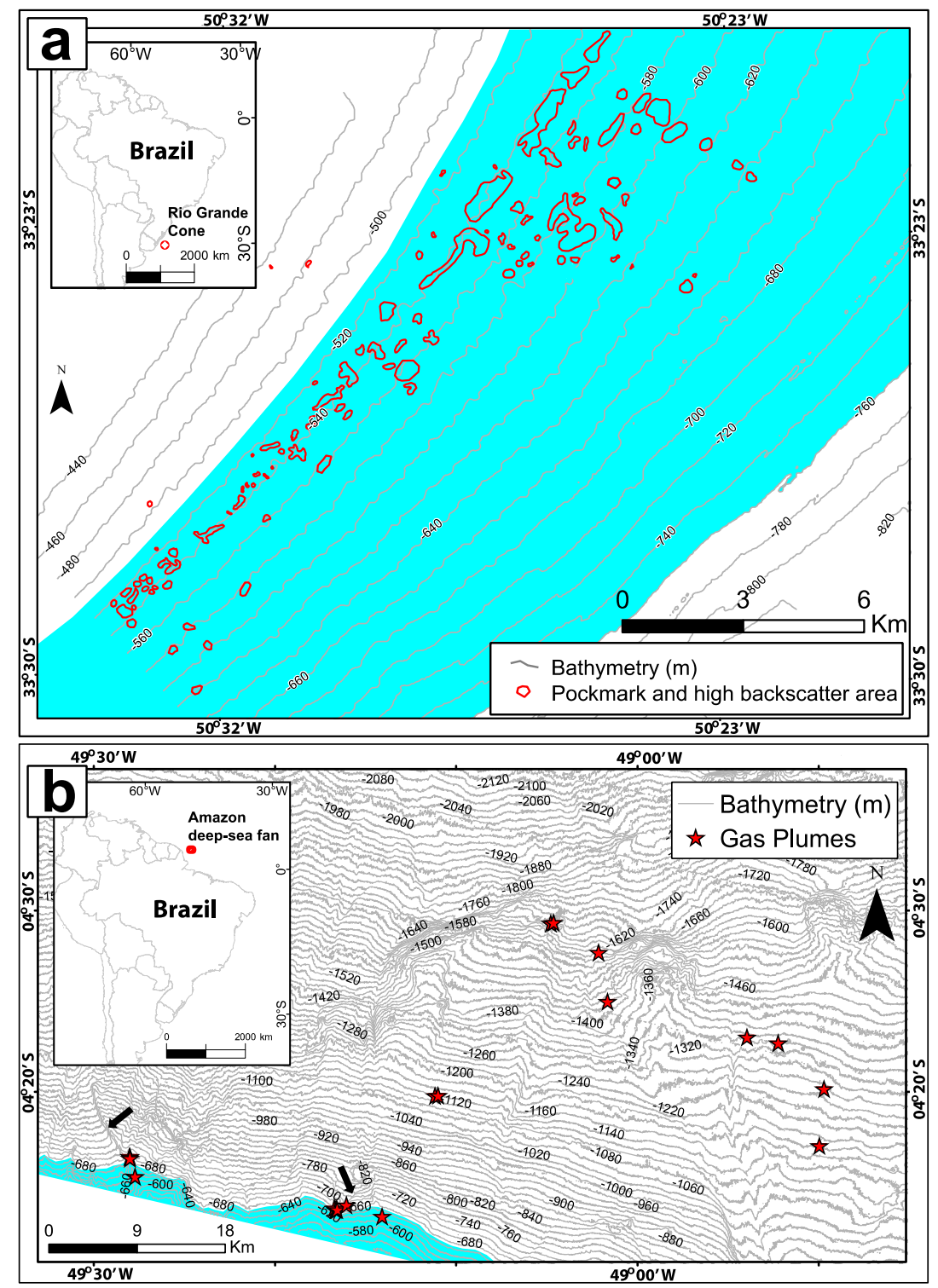

Figure 1. Maps showing bathymetric contours derived from multibeam data across the two areas in Brazil where there is evidence of gas seepage near the feather edge of the methane hydrate stability zone: (a) The Rio Grande Cone, Pelotas Basin, western South Atlantic (modified from [46]) and (b) the Amazon deep-sea fan, Foz do Amazonas Basin, Equatorial Atlantic Ocean (modified from [47]). The areas in light blue mark the depth range of the feather edge of the gas hydrate stability zone calculated for the two regions using pure methane in seawater [48], and water temperature measurements obtained for the regions from the World Ocean Database (WOD18 [49]; see Figure 2). Red areas in (a) are pockmarks and high backscatter areas aligned with both subjacent NE-SW faults and the feather edge of the GHSZ (for details see [46]). Red stars in (b) are water column gas plumes, and black arrows indicate trace of faults on the seafloor near gas seeps at the edge of the methane hydrate stability zone (for details see [47]). 

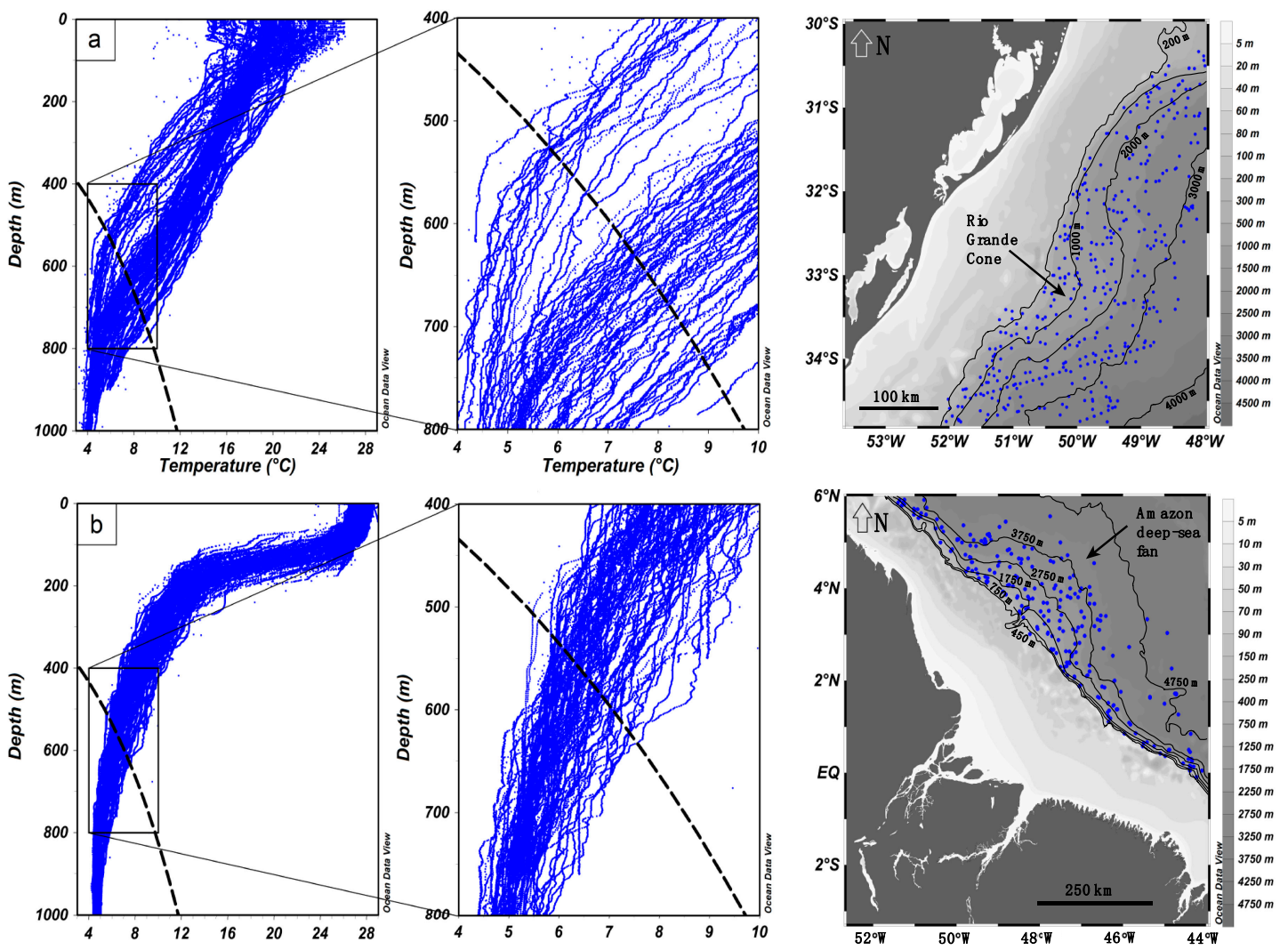

Figure 2. Water temperature profiles for (a) the Rio Grande Cone and (b) Amazon deep-sea fan from the World Ocean Database (WOD18 [49]). The dashed line indicates the phase boundary for pure methane in seawater [47]. Blue dots in the bathymetric maps to the right indicate the location of the temperature profiles.

Direct evidence of natural gas hydrate and gas seeps on the seafloor were found in the Rio Grande Cone [46] and in the Amazon deep-sea fan [47] —in both areas in association with gas venting from the GHSZ. Living chemosynthesis-based communities in pockmarks in the Rio Grande Cone [50,51], in addition to acoustic disturbance caused by the presence of free gas at shallow depths $(<10 \mathrm{~m})$ below seafloor in sub-bottom profiles [52], are indicative of active methane seeps. Direct evidence of gas seepage was identified in the Amazon deep-sea fan by the presence of acoustic anomalies in the water column using multi-beam echo sounder backscatter data, which is also supported by the presence of remnants of chemosynthetic organisms at the seafloor [47]. In both areas, gas vents occur both within the GHSZ and along its edge, and are inferred to be influenced by normal and thrust faults related to the gravitational tectonics induced by sediment loading [46,47]. Gas hydrate was recovered and sampled in both areas in piston cores at water depths from 550-1400 m below sea level (mbsl) in the Rio Grande Cone [46], and at 1000-1800 mbsl in the Amazon deep-sea fan [47]. In both cases, dominantly $\mathrm{CH}_{4}$ composition with $\delta^{13} \mathrm{C}<-66.7 \%$ o V-PDB (Vienna-Pee Dee Belemnite standard) for the Rio Grande Cone and $\delta^{13} \mathrm{C}<-77.3 \%$ o V-PDB for the Amazon deep-sea fan indicate a biogenic origin for the methane trapped in hydrate.

\section{The Edge of the Stability Zone and Seafloor Gas Vents}

The theoretical depth range of the feather edge of the methane hydrate stability zone (MHSZ) can be calculated using an equilibrium equation for pure methane hydrate in seawater [48]:

$$
\mathrm{T}=11.726+20.5 \times \log _{10} \mathrm{z}-2.2 \times\left(\log _{10} \mathrm{z}\right)^{2}
$$

where $\mathrm{T}$ is the temperature of the phase boundary $\left({ }^{\circ} \mathrm{C}\right)$ and $\mathrm{z}$ is the depth $(\mathrm{km})$. 
The upper depth limit of the MHSZ can be estimated using the above equation and historical (1958 to 2018) water column temperature data from the World Ocean Database (WOD18 [49]), which show high variability in measured temperatures above $900 \mathrm{~m}$ water depth in both areas of interest (5.4 to $9.3^{\circ} \mathrm{C}$ in the Rio Grande Cone and 5.4 to $7.6^{\circ} \mathrm{C}$ in the Amazon fan; Figure 2). The feather edge of the MHSZ is thus constrained within a range of depths, between 510 and $760 \mathrm{mbsl}$ on the Rio Grande Cone and between 500 and $670 \mathrm{mbsl}$ on the Amazon deep-sea fan. Comparison of these depth ranges with recently published observations based on water column, seafloor, and sub-bottom acoustic imagery and samples from piston cores $[45,46,51]$ indicates that gas seeps occur both within and near the edge of the GHSZ in the two studied areas (Figure 1).

On the Rio Grande cone, multibeam bathymetric and backscatter imagery reveal pockmark fields in two main locations: On the mid-slope in water depths of ca. $1300 \mathrm{~m}$ (ca. $320 \mathrm{~km}^{2}$ with a pockmark density of ca. $1 / \mathrm{km}^{2}$, or $51 \%$ of the vent sites), and on the upper slope in depths of 520-660 m (ca. 38 $\mathrm{km}^{2}$, with a pockmark density of $8 / \mathrm{km}^{2}$; or $49 \%$ of the vent sites; Figure 1). In both areas, pockmarks are high backscatter features of variable relief, with their long axes parallel to subjacent extensional faults [46]. The upper pockmark field lies within the estimated depth range of the MHSZ feather edge (510-760 m) and comprises a slope-parallel zone $20 \mathrm{~km}$ long by $3 \mathrm{~km}$ wide, widening to $6 \mathrm{~km}$ in the NW, including a central zone where pockmarks cover most of the seafloor (Figure 1). Sub-bottom profiles across pockmarks show acoustic blanking, consistent with free gas rising to the seafloor through chimney-like features [46,52]. Methane concentration and sulphate profiles in pore waters obtained from piston cores samples in a cross-section perpendicular to the pockmark field corroborate with the presence of shallow gas, notably focused at the $545 \mathrm{~m}$ isobath [52], where there is a major concentration of pockmarks in the field [46]. The sulphate methane interface is considerably shallower within the pockmark field (3-4 mbsf) compared to a background area downslope within the GHSZ at ca. 1300 mbsl (ca. $>10 \mathrm{mbsf}$ [52]). The data suggest, therefore, the existence of active methane seeps within the pockmark field. The presence of authigenic carbonate concretions (centimeters in diameter) in piston cores [46], for which the radiometric ages are yet to be determined, indicates that the seeps may have been active for thousands of years (assuming a growth rate of ca. $0.4-0.8 \mathrm{~cm} / \mathrm{kyr}$ [53]). Foraminiferal stable carbon isotope and sediment mineralogy found in ancient pockmarks in the northern portion of the Pelotas Basin (200 km north of the Rio Grande Cone) indicate seafloor methane release during the last glacial period (40-20 cal ka BP, Before Present, [54]).

On the upper Amazon deep-sea fan, multibeam water column and seafloor data acquired across water depths of 650-2600 m reveal the existence of at least 53 gas plumes rising up to $900 \mathrm{~m}$ into the water column from seafloor venting features that include both pockmarks and mounds [47]. Most of the gas vents $(60 \%)$ are located within the MHSZ along lineaments corresponding to faults that may have acted as pathways for fluid migration [47], whereas some $(40 \%)$ are located in water depths of 650-715 $\mathrm{m}$ within the feather edge of the MHSZ (500-670 m) along about $50 \mathrm{~km}$ of its length (Figure $1 \mathrm{~b}$ ). The latter features include 23 water column gas plumes that rise up to $350 \mathrm{~m}$ into the water column from seafloor mounds 10-20 m high [47]. The gas bubble plumes were not sampled, but 24 dissolved and free gas and three gas hydrate samples in piston cores at plume sites revealed a dominantly methane composition (with the absence of heavier hydrocarbons), and a strong depletion in ${ }^{13} \mathrm{C}\left(\delta^{13} \mathrm{C}\right.$ from -102.2 to $-73.7 \%$ o, V-PDB), indicating a biogenic origin [55].

\section{Discussion}

Brazil's continental margin contains at least two major gas hydrate provinces, located in depocenters in which rapid deposition drives tectonism, fluid migration, and methanogenesis, providing ideal conditions for near-surface gas hydrate accumulation [46,47]. In both provinces, gas hydrates have been sampled from seafloor venting structures that indicate gas seepage is taking place within the GHSZ and along its feather edge. Gas venting to the oceans within the GHSZ has been reported from many other deep-water settings $[27,28]$ and linked to the formation of chimney-like features within the GHSZ [56]. Mechanisms to account for such features all involve the upward 
migration of warm gas-rich fluids, which modify the base of the GHSZ and/or sediment properties within it [57-59]. Such mechanisms have yet to be tested against evidence from the deep-water gas vents on the Brazilian margin. Nonetheless, the fact that many of the vents observed within the two areas investigated to date are associated with seafloor faults related to gravity tectonics (e.g., $51 \%$ in the Rio Grande Cone and $60 \%$ in the Amazon deep-sea fan) $[46,47]$ provides evidence that processes internal to continental margin depocenters may be important in the creation of fluid migration pathways into and through the GHSZ.

Evidence of structurally-influenced gas venting through the GHSZ on the Brazilian margin raises questions regarding the origin of the gas vents observed along its feather edge. Gas seeps observed in similar settings around the world have been suggested to record the dissociation of gas hydrates in response to ocean warming [26,27]. This is also possible on the Brazilian margin, as recorded variations in water temperatures, which record cyclic or progressive changes in the water masses that impinge on the upper slope over decadal timescales, imply that the edge of the GHSZ has migrated across large depth ranges (Figures 1 and 2). The Rio Grande cone and Amazon fan include seeps within the areas corresponding to these depth ranges, which could record gas hydrate dissociation. However, seeps in both areas contain evidence of deeper structural influences, notably on the Rio Grande cone where a slope-parallel field of elongate pockmarks is aligned with both subjacent faults and the edge of the GHSZ. The location of seeps relative to the edge of the GHSZ might be related to a complex interplay among structures focusing gas flow to the seafloor and the geomechanics of sediments during hydrate dissociation [60], the geometry of the edge of the GHSZ [61], gas migration along the base of the GHSZ to escape at its edge [62], and the dynamics of bottom water temperature changes-including multidecadal warming and shoaling of Antarctic Intermediate Water observed in the region [63]. The dynamics of the Antarctic Intermediate Water in particular may be an important component for the stability of gas hydrate deposits in the South Atlantic Ocean margins (and the Rio Grande Cone), where warming between 0.01 and $0.02{ }^{\circ} \mathrm{C} \cdot$ year $^{-1}$ has been observed since the 1970s [63]. Using the equilibrium equation for pure methane hydrate in seawater [48], it is possible to estimate that such a warming rate could dislocate the feather edge of the GHSZ by several hundreds of meters downslope (tens of meters deeper) in a few decades. Similar warming rates $\left(0.007^{\circ} \mathrm{C} \cdot\right.$ year $\left.{ }^{-1}\right)$ of the North Pacific Intermediate Water resulting in dislocation of the edge of the GHSZ was observed in the Cascadian margin, North Pacific Ocean [14]. More detailed temporal studies relating the downslope dislocation of the feather edge of the GHSZ to bottom water temperature measurements and associated seafloor seeping structures offshore Brazil must be undertaken to determine whether gas hydrate dissociation is linked to long-term (millennia) trends, following the last glacial maximum, and/or short-term (decades) trends related to anthropogenic warming $[12,17,26]$.

Numerical modeling indicates that ocean warming over the last decades may have released significant quantities of methane from global gas hydrate systems $[15,56,64]$. These models have several limitations and assumptions, but provide valuable insights about the potential release of $\mathrm{CH}_{4}$ from hydrate dissociation [5]. On the Cascadia margin, warming along $273 \mathrm{~km}$ of the GHSZ feather edge between 1970 and 2013 is estimated to have released $4.35 \mathrm{Tg}$ of methane to the water column, and may release another 45-80 Tg by 2100 [14]. Modeling of gas hydrate dissociation off North Carolina, in the western Atlantic, suggests that $2.5 \mathrm{Gt}$ of methane was produced over an area of $10,000 \mathrm{~km}^{2}$ by bottom water warming [65]. There are no published models of gas hydrate dissociation offshore South America, thus the possible magnitude of methane release along Brazil's continental margin is unknown. However, if the quantities of carbon released to the oceans are of the same order of magnitude as those modeled for other regions of the world experiencing the same warming rates of bottom waters, and if the observed seepage features can be extrapolated for tens to hundreds of kilometers beyond the limits of the study area, such as in the Cascadia margin [14], the gas venting known to be ongoing in at least two gas hydrate provinces offshore Brazil may be of concern and deserves further investigation.

Over longer timescales, there is a possible connection between gas hydrate dissociation at the edge of the GHSZ and the triggering of landslides within the studied areas. The Amazon fan contains 
a record of recurrent giant landslides sourced on its upper slopes, which have been suggested to record massive dissociation of gas hydrate linked to glacial/interglacial changes in sea level [66], although they have alternatively been linked to collapse tectonics on the upper fan [44]. Mass wasting deposits of a smaller scale are observed near the feather edge of the GHSZ on the Rio Grande cone [52]. A megaslide complex is recognized to the south of the Rio Grande cone, with headwall scarps near the shelf-break and upper slope, although there is no clear association with gas hydrate systems in the area and gravity tectonics has been proposed as the main triggering mechanism [67]. Along most of the continental slope, gas hydrate stability has decreased since the last glacial maximum (LGM) due to the warming of South Atlantic bottom waters by at least $3.5^{\circ} \mathrm{C}$ at a depth of $657 \mathrm{~m}$ on the upper Rio Grande cone [68]. However, investigations of a pockmark field at shallower depths (475 m) at $200 \mathrm{~km}$ to the north of the Pelotas Basin provide evidence of seafloor methane release at the LGM, linked to the impingement of warmer bottom waters on the uppermost slope owing to sea level lowering [54]. The effects of depth-dependent changes in ocean temperatures during the last sea level cycle on gas hydrate stability remain poorly understood offshore Brazil, as on other continental margins, and it is of interest to undertake modeling to examine the possible connection between hydrate dissociation and landslides in the Rio Grande Cone and Amazon deep-sea fan, and explore their geohazard potential [69].

\section{Conclusions}

Brazil's vast continental slope area remains to be fully investigated, but includes two proven gas hydrate provinces: the Amazon deep-sea fan in the far north and the Rio Grande cone in the far south. In both areas, gas venting is observed to take place within the gas hydrate stability zone and near its feather edge, as calculated from bottom water temperatures. Further studies are necessary to determine the extent to which gas venting from the GHSZ is driven by subsurface fluid flow linked to the internal dynamics of the gravitationally collapsing depocenters, or by gas hydrate dissociation at the feather edge of the stability zone linked to changes in ocean conditions over glacial and/or anthropogenic timescales. It is also important to model the quantities of methane that may be transferred from sediments to the oceans in both areas under different scenarios. Considering the possible existence of gas hydrate provinces in other basins along the Brazilian margin, the area provides a natural laboratory for further investigations of gas hydrate dynamics.

Author Contributions: Conceptualization, M.K.; Investigation, M.K., M.A.G.P., A.H.A., L.F.R., A.R.V., D.P., and J.A.C.; Data curation, M.K., M.A.G.P., and A.H.A.; Writing-original draft preparation, M.K.; Writing-review and editing, M.K., M.A.G.P., A.H.A., L.F.R., A.R.V., D.P., and J.A.C.

Funding: D.P. was supported in part by funding from the European Union's Horizon 2020 research and innovation program under Marie Skłodowska-Curie grant agreement No. 656821, and in part from the Brazilian Coordination of Superior Level Staff Improvement CAPES-IODP (2018-2019). This research received no other external funding.

Acknowledgments: The authors thank the editors for the invitation to participate in the Special Issue of the journal Geosciences "Gas Hydrate: Environmental and Climate Impacts".

Conflicts of Interest: The authors declare no conflict of interest.

\section{References}

1. Breitburg, D.; Levin, L.A.; Oschlies, A.; Grégoire, M.; Chavez, F.P.; Conley, D.J.; Garçon, V.; Gilbert, D.; Gutiérrez, D.; Isensee, K.; et al. Declining oxygen in the global ocean and coastal waters. Science 2018, 359, eaam7240. [CrossRef]

2. Dutkiewicz, S.; Morris, J.J.; Follows, M.J.; Scott, J.; Levitan, O.; Dyhrman, S.T.; Berman-Frank, I. Impact of ocean acidification on the structure of future phytoplankton communities. Nat. Clim. Chang. 2015, 5, 1002-1006. [CrossRef]

3. Bruno, J.F.; Bates, A.E.; Cacciapaglia, C.; Pike, E.P.; Amstrup, S.C.; van Hooidonk, R.; Henson, S.A.; Aronson, R.B. Climate change threatens the world's marine protected areas. Nat. Clim. Chang. 2018, 8, 499-503. [CrossRef] 
4. Pachauri, R.K.; Allen, M.R.; Barros, V.R.; Broome, J.; Cramer, W.; Christ, R.; Church, J.A.; Clarke, L.; Dahe, Q.; Dasgupta, P.; et al. Climate Change 2014: Synthesis Report. Contribution of Working Groups I, II and III to the Fifth Assessment Report of the IPCC; Intergovernmental Panel on Climate Change: Geneva, Switzerland, 2014; p. 112.

5. Hunter, S.J.; Goldobin, D.S.; Haywood, A.M.; Ridgwell, A.; Rees, J.G. Sensitivity of the global submarine hydrate inventory to scenarios of future climate change. Earth Planet. Sci. Lett. 2013, 367, 105-115. [CrossRef]

6. Pinero, E.; Marquardt, M.; Hensen, C.; Haeckel, M.; Wallmann, K. Estimation of the global inventory of methane hydrates in marine sediments using transfer functions. Biogeosciences 2013, 10, 959-975. [CrossRef]

7. Dickens, G.R. Down the Rabbit Hole: Toward appropriate discussion of methane release from gas hydrate systems during the Paleocene-Eocene thermal maximum and other past hyperthermal events. Clim. Past 2011, 7, 831-846. [CrossRef]

8. Archer, D. Methane hydrate stability and anthropogenic climate change. Biogeosciences 2007, 4, 521-544. [CrossRef]

9. Giustiniani, M.; Tinivella, U.; Jakobsson, M.; Rebesco, M. Arctic Ocean Gas Hydrate Stability in a Changing Climate. J. Geol. Res. 2013, 2013, 783969. [CrossRef]

10. Ruppel, C.D. Methane Hydrates and Contemporary Climate Change. Nat. Educ. Knowl. 2011, 3, 29.

11. Tinivella, U.; Giustiniani, M.; Accettella, D. BSR versus Climate Change and Slides. J. Geol. Res. 2011, 2011, 390547. [CrossRef]

12. Thatcher, K.E.; Westbrook, G.K.; Sarkar, S.; Minshull, T.A. Methane release from warming-induced hydrate dissociation in the West Svalbard continental margin: Timing, rates, and geological controls. J. Geophys. Res. Solid Earth 2013, 118, 22-38. [CrossRef]

13. Ferré, B.; Mienert, J.; Feseker, T. Ocean temperature variability for the past 60 years on the Norwegian-Svalbard margin influences gas hydrate stability on human time scales. J. Geophys. Res. 2012, 117, C10017. [CrossRef]

14. Hautala, S.; Solomon, E.; Johnson, H.P.; Harris, R.N.; Miller, U.K. Dissociation of Cascadia margin gas hydrates in response to contemporary ocean warming. Geophys. Res. Lett. 2014, 41, 8486-8494. [CrossRef]

15. Stranne, C.; O’Regan, M.; Dickens, G.R.; Crill, P.; Miller, C.; Preto, P.; Jakobsson, M. Dynamic simulations of potential methane release from East Siberian continental slope sediments. Geochem. Geophys. Geosyst. 2016, 17, 872-886. [CrossRef]

16. Hornbach, M.J.; Saffer, D.M.; Holbrook, W.S. Critically pressured free-gas reservoirs below gas-hydrate provinces. Nature 2004, 427, 142-144. [CrossRef]

17. Berndt, C.; Feseker, T.; Treude, T.; Kraster, S.; Liebetrau, V.; Niemann, H.; Bertics, V.J.; Dumke, I.; Dünnbier, K.; Ferré, B.; et al. Temporal constraints on hydrate-controlled methane seepage off Svalbard. Science 2014, 343, 284-287. [CrossRef]

18. Reeburgh, W.S. Oceanic methane biogeochemistry. Chem. Rev. 2007, 107, 486-513. [CrossRef]

19. Regnier, P.; Dale, A.W.; Arndt, S.; La Rowe, D.E.; Mogollón, J.; Van Cappellen, P. Quantitative analysis of anaerobic oxidation of methane (AOM) in marine sediments: A modeling perspective. Earth Sci. Rev. 2011, 106, 105-130. [CrossRef]

20. McGinnis, D.F.; Greinert, J.; Artemov, Y.; Beaubien, S.E.; Wuest, A. Fate of rising methane bubbles in stratified waters: How much methane reaches the atmosphere? J. Geophys. Res. 2006, 111, C09007. [CrossRef]

21. Mau, S.; Valentine, D.L.; Clark, J.F.; Reed, J.; Camilli, R.; Washburn, L. Dissolved methane distributions and air-sea flux in the plume of a massive seep field, Coal Oil Point, California. Geophys. Res. Lett. 2007, 34, L22603. [CrossRef]

22. Leonte, M.; Kessler, J.D.; Kellermann, M.Y.; Arrington, E.C.; Valentine, D.L.; Sylva, S.P. Rapid rates of aerobic methane oxidation at the feather edge of gas hydrate stability in the waters of Hudson Canyon, US Atlantic Margin. Geochim. Cosmochim. Acta 2017, 204, 375-387. [CrossRef]

23. Biastoch, A.; Treude, T.; Rüpke, L.H.; Riebesell, U.; Roth, C.; Burwicz, E.B.; Park, W.; Latif, M.; Böning, C.W.; Madec, G.; et al. Rising Arctic Ocean temperatures cause gas hydrate destabilization and ocean acidification. Geophys. Res. Lett. 2011, 38, L08602. [CrossRef]

24. Boudreau, B.P.; Luo, Y.; Meysman, F.J.R.; Middelburg, J.J.; Dickens, G.R. Gas hydrate dissociation prolongs acidification of the Anthropocene oceans. Geophys. Res. Lett. 2015, 42, 9337A-9344A. [CrossRef]

25. Maslin, M.; Owen, M.; Betts, R.; Day, S.; Jones, T.D.; Ridgwell, A. Gas hydrates: Past and future geohazard? Philos. Trans. R. Soc. A 2010, 368, 2369-2393. [CrossRef] 
26. Westbrook, G.K.; Thatcher, K.E.; Rohling, E.J.; Piotrowski, A.M.; Pälike, H.; Osborne, A.H.; Nisbet, E.G.; Minshull, T.A.; Lanoiselle, M.; James, R.H.; et al. Escape of methane gas from the seabed along the West Spitsbergen continental margin. Geophys. Res. Lett. 2009, 36, 1-5. [CrossRef]

27. Skarke, A.; Ruppel, C.; Kodis, M.; Brothers, D.; Lobecker, E. Widespread methane leakage from the sea floor on the northern US Atlantic margin. Nat. Geosci. 2014, 7, 657-661. [CrossRef]

28. Johnson, H.P.; Miller, U.K.; Salmi, M.S.; Solomon, E.A. Analysis of bubble plume distributions to evaluate methane hydrate decomposition on the continental slope. Geochem. Geophys. Geosyst. 2015, 16, 3825-3839. [CrossRef]

29. Screen, J.A.; Simmonds, I. The central role of diminishing sea ice in recent Arctic temperature amplification. Nature 2010, 464, 1334-1337. [CrossRef]

30. Serreze, M.C.; Barry, R.G. Processes and impacts of Arctic amplification: A research synthesis. Glob. Planet. Chang. 2011, 77, 85-96. [CrossRef]

31. Spielhagen, R.F.; Werner, K.; Sørensen, S.A.; Zamelczyk, K.; Kandiano, E.; Budeus, G.; Husum, K.; Marchitto, T.M.; Hald, M. Enhanced modern heat transfer to the Arctic by warm Atlantic water. Science 2011, 331, 450-453. [CrossRef] [PubMed]

32. Fontana, L.R. Evidencias geofísicas da Presença de Hidratos de Gas na Bacia de Pelotas. In Proceedings of the 1st Congress of the Brazilian Geophysical Society, Rio de Janeiro, Brazil, 20 November 1989.

33. Fontana, R.L.; Mussumeci, A. Hydrates offshore Brazil. In Annals of the New York Academy of Sciences, International Conference on Natural Gas Hydrates; New York Academy of Sciences: New York, NY, USA, 1994; Volume 715, pp. 106-113.

34. Oliveira, S.; Vilhena, O.; da Costa, E. Time-frequency spectral signature of Pelotas Basin deep water gas hydrates system. Mar. Geophys. Res. 2010, 31, 89-97. [CrossRef]

35. Manley, P.L.; Flood, R.D. Cyclic sediment deposition within Amazon deep-sea fan. Am. Assoc. Petrol. Geol. Bull. 1988, 72, 912-925.

36. Tanaka, M.D.; Silva, C.G.; Clennell, M.B. Gas hydrates on the Amazon Submarine Fan, Foz do Amazonas Basil, Brazil. In Proceedings of the AAPG Search and Discovery Article \#90013, AAPG Annual Meeting, Salt Lake City, UT, USA, 11-14 May 2003.

37. Berryman, J.; Kearns, H.; Rodriguez, K. Foz do Amazonas Basin-A case for oil generation from geothermal gradient modelling. First Break 2015, 33, 91-95.

38. Matsuda, N.S.; Freire, A.F.M. The Bottom Simulating Reflector (BSR) along the Brazilian Atlantic Coast: A New Perspective for Gas Hydrates Exploration in the Southern Hemisphere. In Proceedings of the AAPG International Conference and Exhibition, Cape Town, South Africa, 26-29 October 2008.

39. Martins, L.R.; Melo, U.; França, A.M.C.; Santana, C.I.; Martins, I.R. Distribuicao Faciologica da Margem Continental Sul Riograndense. In Proceedings of the XXVI Congresso Brasileiro de Geologia, Belem, Brazil, 26 October 1972; Volume 2, pp. 115-132.

40. Hernándes-Molina, F.J.; Soto, M.; Piola, A.R.; Tomasini, J.; Preu, B.; Thompson, P.; Badalini, G.; Creaser, A.; Violante, R.A.; Morales, E.; et al. A contourite depositional system along the Uruguayan continental margin: Sedimentary, oceanographic and paleoceanographic implications. Mar. Geol. 2016, 378, 333-349. [CrossRef]

41. Viana, A.R. Seismic expression of shallow- to deep-water contourites along the south-eastern Brazilian margin. Mar. Geophys. Res. 2002, 22, 509-521. [CrossRef]

42. Figueiredo, J.; Hoorn, C.; van der Ven, P.; Soares, E. Late Miocene onset of the Amazon River and the Amazon deep-sea fan: Evidence from the Foz do Amazonas Basin. Geology 2009, 37, 619-622. [CrossRef]

43. Damuth, J.E.; Kumar, N. Amazon cone, morphology, sediments, age, and growth pattern. Geol. Soc. Am. Bull. 1975, 86, 863-878. [CrossRef]

44. Reis, A.T.; Araújo, E.; Silva, C.G.; Cruz, A.M.; Gorini, C.; Droz, L.; Migeon, S.; Perovano, R.; King, I.; Bache, F. Effects of a regional décollement level for gravity tectonics on late Neogene to recent large-scale slope instabilities in the Foz do Amazonas Basin, Brazil. Mar. Petrol. Geol. 2016, 75, 29-52. [CrossRef]

45. Sad, A.R.E.; Silveira, D.P.; Machado, D.A.P.; Silva, S.R.P.; Maciel, R.R. Marine gas hydrates evidence along the Brazilian coast. In Proceedings of the AAPG International Conference and Exhibition, Rio de Janeiro, Brazil, 8-11 November 1998.

46. Miller, D.J.; Ketzer, J.M.; Viana, A.R.; Kowsmann, R.O.; Freire, A.F.; Oreiro, S.G.; Augustin, A.H.; Lourega, R.V.; Rodrigues, L.F.; Heemann, R.; et al. Natural gas hydrates in the Rio Grande Cone (Brazil): A new province in the western South Atlantic. Mar. Petrol. Geol. 2015, 67, 187-196. [CrossRef] 
47. Ketzer, J.M.; Augustin, A.; Rodrigues, L.F.; Oliveira, R.; Praeg, D.; Pivel, M.A.G.; Reis, A.T.; Silva, C.G.; Leonel, B. Gas seeps and gas hydrates in the Amazon deep-sea fan. Geo-Mar. Lett. 2018, 38, 429-438. [CrossRef]

48. Dickens, G.R.; Quinby-Hunt, M.S. Methane hydrate stability in sea- water. Geophys. Res. Lett. 1994, 21, 2115-2118. [CrossRef]

49. Boyer, T.P.; Baranova, O.K.; Coleman, C.; Garcia, H.E.; Grodsky, A.; Locarnini, R.A.; Mishonov, A.V.; O’Brien, T.D.; Paver, C.R.; Reagan, J.R.; et al. World Ocean Database 2018; Mishonov, A., Ed.; NOAA: Silver Spring, MD, USA, 2018; 209p.

50. Giongo, A.; Haag, T.; Lopes Simao, T.L.; Medina-Silva, R.; Utz, L.R.P.; Bogo, M.R.; Bonatto, S.; Zamberlan, P.; Augustin, A.H.; Lourega, R.V.; et al. Discovery of a chemosynthesis-based community in the western South Atlantic Ocean. Deep Sea Res. Part Oceanograph. Res. Pap. 2016, 112, 45-56. [CrossRef]

51. Medina-Silva, R.; Oliviera, R.R.; Trindade, F.J.; Trindade, F.J.; Borges, L.G.A.; Simao, T.L.L.; Augustin, A.H.; Valdez, F.P.; Constant, M.; Simundi, C.; et al. Microbiota associated with tubes of Escarpia sp. from cold seeps in the southwestern Atlantic Ocean constitutes a community distinct from that of surrounding marine sediment and water. Antonie Leeuwenhoek Int. J. Gen. Mol. Microbiol. 2017, 111, 533-550. [CrossRef]

52. Rodrigues, L.F.; Ketzer, J.M.; Lourega, R.V.; Augustin, A.H.; Sbrissa, G.; Miller, D.J.; Heemann, R.; Viana, A.R.; Freire, A.F.M.; Morad, S. The influence of methane fluxes on the sulfate/methane interface in sediments from the Rio Grande Cone Gas Hydrate Province, southern Brazil. Braz. J. Geol. 2017, 47, 369-381. [CrossRef]

53. Bayon, G.; Henderson, G.M.; Bohn, M. U-Th stratigraphy of a cold seep carbonate crust. Chem. Geol. 2009, 260, 47-56. [CrossRef]

54. Portilho-Ramos, R.C.; Cruz, A.P.S.; Barbosa, C.F.; Rathburn, A.E.; Mulitza, S.; Venancio, I.M.; Schwenk, T.; Rühlemann, C.; Vidal, L.; Chiessi, C.M.; et al. Methane release from the southern Brazilian margin during the last glacial. Sci. Rep. 2018, 8, 5948. [CrossRef]

55. Rodrigues, L.F.; Ketzer, J.M.; Oliveira, R.R.; Santos, V.H.J.M.; Augustin, A.H.; Cupertino, J.A.; Viana, A.R.; Leonel, B.; Dorle, W. Molecular and isotopic composition of hydrate-bound, dissolved and free gases in the Amazon deep-sea fan and slope sediments, Brazil. Geosciences 2019, 9, 73. [CrossRef]

56. Haacke, R.R.; Hyndman, R.D.; Park, K.P.; Yoo, D.G.; Stoian, I.; Schmidt, U. Migration and venting of deep gases into the ocean through hydrate choked chimneys offshore Korea. Geology 2009, 37, 531-534. [CrossRef]

57. Liu, X.; Flemings, P.B. Dynamic multiphase flow model of hydrate formation in marine sediments. J. Geophys. Res. Solid Earth 2007, 112, B03101. [CrossRef]

58. Hornbach, M.J.; Ruppel, C.; Van Dover, C.L. Three dimensional structure of fluid conduits sustaining an active deep marine cold seep. Geophys. Res. Lett. 2007, 34, L05601. [CrossRef]

59. Riedel, M.; Tréhu, A.M.; Spence, G.D. Characterizing the thermal regime of cold vents at the northern Cascadia margin from bottom simulating reflector distributions, heat probe measurements and borehole temperature data. Mar. Geophys. Res. 2010, 31, 1-16. [CrossRef]

60. Stranne, C.; O’Regan, M.; Jakobsson, M. Modeling fracture propagation and seafloor gas release during seafloor warming-induced hydrate dissociation. Geophys. Res. Lett. 2017, 44, 8510-8519. [CrossRef]

61. Gorman, A.R.; Senger, K. Defining the updip extent of the gas hydrate stability zone on continental margins with low geothermal gradients. J. Geophys. Res. 2010, 115, B07105. [CrossRef]

62. Horozal, S.; Bahk, J.J.; Urgeles, R.; Kim, G.Y.; Cukur, D.; Kim, S.P.; Lee, G.H.; Lee, S.H.; Ryu, B.J.; Kim, J.H. Mapping gas hydrate and fluid flow indicators and modeling gas hydrate stability zone (GHSZ) in the Ulleung Basin, East (Japan) Sea: Potential linkage between the occurrence of mass failures and gas hydrate dissociation. Mar. Pet. Geol. 2017, 80, 171-191. [CrossRef]

63. Schmidtko, S.; Johnson, G. Multidecadal Warming and Shoaling of Antarctic Intermediate Water. J. Clim. 2012, 25, 207-221. [CrossRef]

64. Stranne, C.; O'Regan, M.; Jakobsson, M. Overestimating climate warming-induced methane gas escape from the seafloor by neglecting multiphase flow dynamics. Geophys. Res. Lett. 2016, 43, 8703-8712. [CrossRef]

65. Phrampus, B.J.; Hornback, M.J. Recent changes to the Gulf Stream causing widespread gas hydrate destabilization. Nature 2012, 490, 527-529. [CrossRef]

66. Maslin, M.; Vilela, C.; Mikkelsen, N.; Grootes, P. Causes of catastrophic sediment failures of the Amazon fan. Quat. Sci. Rev. 2005, 24, 2180-2193. [CrossRef] 
67. Reis, A.T.; Silva, C.G.; Gorini, M.A.; Leao, R.; Pinto, N.; Perovano, R.; Santos, M.V.M.; Guerra, J.V.; Jeck, I.K.; Tavares, A.A. The Chui Megaslide Complex: Regional-Scale Submarine Landslides on the Southern Brazilian Margin. In Submarine Mass Movements and their Consequences, Advances in Natural and Technological Hazards Research 41; Lamarche, G., Mountjoy, J., Bull, S., Hubble, T., Krastel, S., Lane, E., Micallef, A., Moscardelli, L., Mueller, C., Pecher, I., et al., Eds.; Springer: Cham, Switzerland, 2016.

68. Chiessi, C.M.; Mulitza, S.; Paul, A.; Pätzold, J.; Groeneveld, J.; Wefer, G. South Atlantic interocean exchange as the trigger for the Bølling warm event. Geology 2008, 36, 919-922. [CrossRef]

69. Milkov, A.V.; Sassen, R.; Novikova, I.; Mikhailov, E. Gas hydrates at minimum stability water depths in the Gulf of Mexico: Significance to Geohazard Assessment. Gulf Coast Assoc. Geol. Soc. Trans. L 2000, 50, 217-224.

(C) 2019 by the authors. Licensee MDPI, Basel, Switzerland. This article is an open access article distributed under the terms and conditions of the Creative Commons Attribution (CC BY) license (http://creativecommons.org/licenses/by/4.0/). 